JIIP: Jurnal IImiah IImu Pemerintahan

Volume 5, Nomor 1, Tahun 2020

DOI: $10.14710 /$ jiip.v5i1.7476

\title{
Bagaimana Kandidat Minoritas Memenangkan Pilkada: Analisis Strategi Politik dalam Bingkai Bourdieusian
}

\author{
Krista Yuliani ${ }^{1}$, Hendra Try Ardianto ${ }^{2}$ \\ ${ }^{1}$ Program Studi Ilmu Pemerintahan, Universitas Diponegoro \\ ${ }^{2}$ Departemen Politik dan Pemerintahan, Universitas Diponegoro
}

\section{Intisari}

Artikel ini bertujuan untuk memberi gambaran bagaimana seorang kandidat dari kelompok minoritas, bisa memenangkan pemilu, padahal lawan yang dihadapinya adalah calon petahana (imcumbent). Guna memenuhi tujuan itu, artikel ini berangkat dari penelitian studi kasus tentang kemenangan Budhi Sarwono sebagai kandidat Tionghoa (Muslim) saat Pilkada 2017 di Banjarnegara. Dalam penggalian data, penulis melakukan wawancara mendalam terhadap kandidat, para petinggi partai di tingkat lokal, serta warga yang mengetahui dinamika politik saat itu. Temuannya adalah keberhasilan Budhi Sarwono dalam Pilkada 2017 adalah hasil dari equivalensi antara habitus warga yang marah karena infrastruktur jalan di kawasan dataran tinggi banyak yang rusak; bertemu dengan ranah politik vis-a-vis petahana; dan injeksi modal kandidat (modal sosial-kultural, ekonomi, politik) yang dikapitalisasi untuk meraih suara warga. Kesimpulannya, strategi politik akan berjalan efektif jika mempertimbangkan bagaimana komposisi ranah, habitus, dan modal kandidat agar bisa saling terjahit secara koheren.

habitus; minoritas; modal ekonomi; modal sosial; pilkada; praktik sosial; Tionghoa

\section{Pendahuluan}

enelitian ini akan membahas bagaimana strategi politik dalam perspektif praktik sosial yang dilakukan oleh Budhi Sarwono pada Pemilihan Kepala Daerah Banjarnegara tahun 2017. Sosok Budhi yang berasal dari kalangan minoritas kemudian berhasil menjadi kepala daerah Banjarnegara tersebut cukup menyita perhatian. Pasalnya, sebelumnya ia pernah kalah dalam pemilihan kepala daerah tahun 2011. Melihat sedikitnya etnis minoritas yang berhasil menduduki jabatan tertinggi di daerah, kemenangan Budhi Sarwono dalam pilkada 2017 silam menarik untuk ditelaah lebih jauh.

Sebagaimana diketahui, di era Orde Baru, etnis Tionghoa dipaksa pindah agama, ganti nama, bahkan pernikahan antar etnis (Oh, 2017, pp. 5639-5640). Tidak hanya itu 
Orde baru juga melarang etnis Tionghoa untuk terlibat dalam politik, bahkan berorganisasi pun dilarang (Suhandinata, 2009, p. 326; Suryadinata, 2003, p. 2). Padahal, di era kolonialisme Belanda, pernah ada Partai Tionghoa Indonesia (PTI) yang bahkan terlibat dalam pergerakan kemerdekaan Indonesia (CNN Indonesia, 2019). Baru saat mulai Reformasi, negara menghapuskan peraturan-peraturan yang membatasi hak warga negara minoritas khususnya etnis Tionghoa dalam politik. Lebih dari itu, menjelang Pemilu 1999, lahir tiga partai yang digawangi oleh komunitas Tionghoa, yakni Partai Bhinneka Tunggal Ika Indonesia, Partai Reformasi Tionghoa Indonesia, Partai Pembauran Indonesia. Sayangnya, hanya Partai Tunggal Ika Indonesia saja yang akhirnya lolos dalam pemilu, dan itu pun hanya menyumbangkan satu kursi saja di DPR (Juliastutik, 2010, pp. 48-49).

Puluhan tahun mengalami pengekangan hak politik, tentu bukan hal mudah bagi etnis Tionghoa untuk terlibat dalam politik elektoral. Seorang kandidat harus memiliki daya tawar yang besar agar partai politik mau memberikan tiketnya pada seorang kandidat. Apalagi, dalam banyak hal, sosok yang dicalonkan oleh pengurus partai di tingkat daerah biasanya harus mendapat persetujuan dari pengurus partai di tingkat pusat (Hanafi, 2016, p. 2). Melihat kondisi itu, menarik untuk mempelajari bagaimana Budhi Sarwono berhasil memenangkan kontestasi dalam pilkada. Strategi seperti apa yang ia lakukan? Mengapa strategi tersebut yang dipilih? Beberapa pertanyaan ini akan dielaborasi lebih jauh dalam artikel ini.

Studi strategi politik sendiri bukan hal baru. Dengan menggunakan pendekatan teori permainan, Saifuddin, Tastrawati, and Sari (2018) menyoroti bagaimana strategi politik yang dilakukan pada pilkada DKI Jakarta 2017 memanfaatkan kesalahan lawan dalam bertindak untuk mendapatkan simpati masyarakat. Kemudian Fatimah (2018) melihat kegagalan strategi politik terletak pada keabaian pada kelemahan lawan. Sedangkan Hudayana (2011) mencermati praktik 'glembuk' (penipuan diam-diam) sebagai strategi paling efektif untuk memenangkan pemilihan. Meskipun demikian, ketiga penelitian terlalu menitik beratkan pada strategi politik, tanpa mengupas lebih dalam sumber daya yang dimiliki kandidat. Abainya analisis terkait modal kandidat, menjadikan pintu masuk bagi artikel ini untuk mengisi kekosongan tersebut.

Dalam mengerjakan artikel ini, penulis melakukan penelitian kualitatif dengan metode studi kasus (case study). Metode studi kasus dipilih karena penulis dapat menjalarkan kajian secara detail terhadap kasus yang menjadi lokus kajian, yaitu batasan-batasan tertentu seperti waktu dan aktivitas (Creswell, 2016, p. 19)'. Karena karakter kualitatif tidak lepas dari gagasan, pandangan, pendapat, atau entitas yang diyakini oleh masyarakat yang seluruhnya tidak dapat diukur dengan angka, maka penggalian data memakai perpaduan dari wawancara observasi, dan dokumentasi. Sedangkan untuk keperluan analisis, penelitian ini menggunakan dua teoritisasi utama, yakni teori strategi politik yang dikemukakan Schroder dan praktik sosial dari Pierre Bourdieu. 


\section{Strategi Politik dan Praktik Sosial sebagai Perangkat Analisis}

Strategi politik adalah usaha yang dilakukan untuk mencapai tujuan politis (Schroder, 2010, p. 27). Dalam prosesnya, penyusunan strategi perlu dipertimbangkan dengan memerhatikan strategi lawan. Strategi yang dipilih harus memerhatikan profil, program, kinerja, serta kemampuan dari kandidat itu sendiri. Pada ranah politik, strategi dilakukan untuk memperoleh kekuasaan. Sehingga diperlukan strategi yang dapat mempengaruhi proses menuju kekuasaan. Dalam kontes pilkada, strategi politik yang dibuat harus disesuaikan dengan kondisi masyarakat agar dapat mempengaruhi mereka untuk memberikan hak pilihnya. Peran individu atau calon kepala daerah dalam sebuah penyusunan strategi diperlukan terutama dalam pengorganisasian. Masyarakat akan mempertimbangkan sosok yang bertarung dalam pilkada berdasarkan penilaian individu melalui tiga unsur, yakni popularitas, citra, serta dukungan internal (Schroder, 2010, pp. 102-104).

Pertama adalah tingkat popularitas, dimana tim pemenangan harus memperhatikan sejauh mana calonnya dikenal oleh masyarakat. Semakin tinggi tingkat popularitas kandidat, maka akan semakin mudah diterima oleh masyarakat atas apa yang disampaikan. Kedua adalah citra atau persona. Setiap kandidat yang ingin maju dalam kontes pilkada memerlukan citra yang positif untuk ditunjukkan kepada masyarakat. Karena citra diperlukan masyarakat untuk mendapatkan gambaran mengenai karakter calon pemimpin mereka, sehingga akan mempermudah proses penilaian. Dalam prosesnya, citra memiliki relasi yang cukup kuat dengan tingkat popularitas. Dimana tingginya tingkat popularitas dapat mempengaruhi citra yang terbentuk di tengah masyarakat. Sehingga, bagi kandidat yang memiliki tingkat popularitas tinggi dibutuhkan kebijaksanaan untuk bertindak di hadapan umum. Ketiga adalah adanya dukungan internal. Bentuk dukungan internal sendiri dapat berasal dari dukungan partai partai politik dan/atau dukungan organisasi yang diikuti oleh kandidat. Dukungan internal diperlukan oleh masyarakat untuk melihat sejauh mana kandidat yang ada mendapat kepercayaan serta dukungan penuh dari lingkungan sekitarnya. Selain itu, dukungan internal juga diperlukan untuk mengatasi cibiran negatif dari kelompok lawan. Dengan dukungan internal yang solid dan kompak, maka kandidat tetap bisa memperlihatkan citra bahwa ia tidak terpengaruh terhadap penilaian negatif dari lawan. Namun pada akhirnya ketiga hal di atas memiliki keterkaitan satu sama lain. Baik tingkat popularitas, citra, maupun dukungan internal ketiganya diperlukan untuk memperoleh penilaian yang positif dari masyarakat.

Dari penjelasan Schroder di atas, maka bisa ditarik sebuah benang merah yang tersabung dengan pemikiran Pierre Bourdieu, utamanya tentang kekuasaan simbolik yang melekat dari praktik sosial seseorang. Kebutuhan akan popularitas, citra, dan dukungan internal, merupakan pengejawantahan dari hasrat meraih kekuasaan simbolik. Guna meraih kekuasan simbolik ini, maka sesorang harus mengarahkan daya usahanya dalam praktik sosial sehari-harinya. Untuk menyederhanakan penjelasan tersebut, Bourdieu mengemukakan rumus umum tentang praktik sosial yakni: (Habitus x Modal) + Ranah = Praktik (Evens, 1999) . 
Habitus merupakan 'struktur kognitif', yakni dengan entitas tersebut makhluk sosial berinteraksi dengan dunia sosial (Ritzer, 2012, p. 581). Habitus juga dapat diartikan sebagai perbuatan yang dilakukan baik secara sadar maupun tidak sadar oleh individu atau kelompok yang kemudian diartikan sebagai perbuatan yang dilakukan secara alami dan berkembang dalam lingkungan sosial tertentu. Habitus disini berarti bahwa perbuatan yang dilakukan tidak selalu berdasar pada peraturan atau norma yang ada di masyarakat, namun kemudian karena dilakukan secara berkala dan berkesinambungan sehingga dianggap seagai pola perbuatan yang alamiah. Habitus yang terbentuk juga dapat berasal dari perbuatan yang disadari dan/atau tidak disadari. Habitus yang terbentuk dari perbuatan seseorang dapat menjadi modal kandidat dalam rangka pencalonan dirinya sehingga dapat mendulang perolehan suara pada pemilihan. Karena tanpa disadari, sebuah habitus positif yang terbentuk di tengah masyarakat dan disadari keberadaannya oleh masyarakat dapat dijadikan acuan atau nilai positif yang dimiliki oleh pemilik habitus tersebut.

Sedangkan untuk memahami mengenai susunan dan cara berfungsinya kehidupan sosial, diperlukan pembahasan mengenai modal secara umum. Besaran modal sosial yang ada pada anggota dari suatu organisasi atau kelompok bergantung pada tingkatan baik kualitas maupun kuantitas interaksi yang dibentuk, serta seberapa besar jumlah modal ekonomi, modal budaya, modal sosial, dan modal politik yang dimiliki oleh setiap anggota pada organisasi tersebut (Bourdieu, 2011, p. 249). Habitus dan modal inilah yang disebut Bourdeu sebagai dimensi subjektif. Sedangkan dimensi objektifnya terletak pada ranah, yang berstatus sebagai arena pertarungan. Oleh karena itu, habitus mempengaruhi terbentuknya ranah, sedangkan ranah menjadi lokus kerja habitus

\section{Budhi Sarwono dan Modal Simboliknya}

Kabupaten Banjarnegara merupakan salah satu Kabupaten di provinsi Jawa Tengah dengan total penduduk pada 2017 berjumlah 912.917 (BPS Kabupaten Banjarnegara, 2018). Sesuai topografi Kabupaten Banjarnegara yang terletak di dataran tinggi, masyarakatnya kemudian banyak yang bekerja sebagai petani. Dahulu, kata Banjar menunjukkan bahwa daerah tersebut merupakan daerah pertanian yang berpetak-petak (banjar) di sepanjang daerah aliran Sungai Serayu. Saat ini, mayoritas masyarakat Banjarnegara bekerja sebagai petani di kawasan dataran tinggi Dieng.

Banjarnegara merupakan salah satu kabupaten yang turut serta dalam proses pilkada serentak yang dilaksanakan pada 2017 silam. Dalam kontes ini, terdapat tiga pasangan calon yang mencalonkan diri menjadi kandidat Kepala Daerah Kabupaten Banjarnegara, yakni: (1) Hadi Supeno-Nur Heni Widiyanti, (2) Wahyu Kristianto-Saeful Muzad, serta (3) Budhi Sarwono-Syamsudin. Pilkada tersebut kemudian dimenangkan oleh pasangan Budhi Sarwono-Syamsudin, mengalahkan petahana Hadi Supeno yang sebelumnya menjabat sebagai wakil bupati Banjarnegara periode 2011-2016 (Aziz, 2017). Peristiwa ini menjadi cukup menarik karena Budhi Sarwono dapat mengalahkan 
petahana yang di masa pemerintahannya mendapat predikat kinerja kategori Sangat Tinggi dari Kementerian Dalam Negeri (Paramita \& Islahuddin, 2017). Dinamika politik ini menjadi sangat menarik bagaimana kandidat pendatang dapat mengalahkan calon petahana yang justru mendapat perolehan suara terendah.

Pilkada Banjarnegara diikuti oleh total 779.379 pemilih dengan tingkat partisipasi masyarakat sebesar 70\% (KPU RI, 2017). Angka ini berada di bawah target yang ditetapkan oleh KPU sebesar 77,5\% (Maharddhika, 2016). Dinamika politik ini dilatarbelakangi oleh berbagai hal, seperti alasan pekerjaan, maupun ikatan emosional. Partisipasi politik masyarakat tertinggi berada di Kecamatan Madukara dengan prosentase sebesar $79,1 \%$. Sedangkan 19 kecamatan lain bervariasi berada di angka 60 77\%. Dua kecamatan yang memiliki partisipasi masyarakat dengan angka cukup tinggi yakni Kecamatan Wanayasa $(77 \%)$, dan Kecamatan Batur $(73,3)$ yang dua-duanya merupakan kecamatan di kawasan dataran tinggi.

Adapun Budhi Sarwono adalah Bupati terpilih Kabupaten Banjarnegara periode 2017-2022. Dirinya merupakan keturunan Tionghoa dan biasa dipanggil Wing Chin oleh masyarakat sekitar. Dalam perjalanan hidupnya, Budhi akhirnya pindah agama menjadi muslim, inilah mengapa dalam artikel ini dirinya kami sebut sebagai Muslim Tionghoa. la pernah mencalonkan diri menjadi Bupati Banjarnegara pada pilkada 2011 melalui jalur independen, namun kalah dengan selisih suara kurang lebih 4 persen saja. Kemudian ia ikut berkontestasi lagi pada Pilkada 2017 dan terpilih menjadi bupati dengan pasangannya Syamsudin sebagai wakilnya, serta Partai Demokrat, PPP, serta Partai Golkar sebagai partai pengusungnya.

Sebagai sosok yang cukup terkenal di Banjarnegara, kesehariannya-sebelum menjadi bupati-banyak dikenal sebagai seorang pengusaha di bidang konstruksi yang gemar menampung gelandangan dan pengemis. Bahkan setelah menjadi Bupati masih memiliki kegiatan untuk mengurus orang dengan gangguan kejiwaan. Beberapa tindakan yang budiman inilah yang membuat namanya kian dikenal sebagai sosok bupati yang dekat dengan rakyat kecil. Sudah menjadi rahasia umum bagi masyarakat Banjarnegara jika Budhi merupakan sosok dermawan yang tidak eman memberikan bantuan. Bisa dikatakan, modal sosial terbesar Budhi adalah sisi kedermawanannya yang akhirnya bisa dimobilisasi sebagai modal politik saat mencalonkan diri sebagai Bupati.

Modal sosial ini ditransformasikan sebagai modal politik untuk mempermudah jalan dirinya dalam meraup suara yang cukup bahkan mampu mengalahkan bupati petahana (incumbent). Sebagai pengusaha konstruksi, dirinya juga diketahui memperbaiki beberapa jalan yang rusak. Dalam spot jalan yang diperbaikinya tersebut, dia kemudian memasang baliho yang berisi foto dan namanya sendiri. Baliho tersebut dapat disebut sebagai alat peraga kampanye yang membantu memperkenalkan Budhi 
Sarwono kepada calon pemilihnya. la mengakui, cara tersebut merupakan salah satu taktik dalam mengangkat namanya sehingga cukup dikenal oleh masyarakat tanpa perlu melakukan safari politik (wawancara penulis, 15 Oktober 2019).

Sebagai pengusaha, modal ekonomi Budhi juga cukup kuat. Dalam Laporan Penerimaan dan Pengeluaran Dana Kampanye (LPPDK) yang disetorkan kepada KPUD Banjarnegara, tertera bahwa ia melaporkan 3,7 miliar untuk dana kampanye. Namun saat di wawancara, ia mengaku menghabiskan sekitar 45 miliar untuk keseluruhan proses dalam pilkada. Anggaran ini dibagi ke dalam pos pengeluaran yang berbeda, diantaranya adalah: biaya survey, biaya kegiatan tim pemenangan serta tim relawan, pembuatan Alat Peraga Kampanye (APK) serta pemasangannya, biaya perbaikan ruas jalan, dan biaya safari politik. Budhi tidak menyebutkan mahar politik dalam pos pengeluaran anggarannya, karena ia mengaku tidak dimintai oleh partai politik. Meski demikian, di lain kesempatan, Endon Priyatno selaku Ketua DPC Partai Demokrat Banjarnegara menyatakan bahwa Budhi Sarwono memberikan "sumbangan" berupa mobil ambulance untuk partai (wawancara penulis, 16 Oktober 2019).

Adapun dalam konteks modal sosial dan budaya, Budhi memanfaatkan jejaring keluarganya untuk mengkapitalisasi suara, khususnya suara perempuan. Untuk kebutuhan tersebut, Budhi membentuk Tim Srikandi yang diketuai anaknya sendiri, Lasmi Indaryani, yang berperan yang cukup penting dalam proses kemenangan Budhi Sarwono pada pilkada 2017 silam. Melalui Tim Srikandi, ia mencoba menarik suara kelompok perempuan. Budhi sadar bahwa perempuan kurang mendapat porsi yang cukup dalam kancah politik. Tim Srikandi inilah yang menggodok citra Budhi sebagai sosok yang rendah hati, serta mudah bergaul, khususnya dikalangan pemilih perempuan.

Pembentukan Tim Srikandi ini memanglah tepat, mengingat tiadanya gugus tugas khusus terkait segmen perempuan di kandidat-kandidat lainnya. Budhi secara sadar hendak memanfaatkan suara perempuan secara signifikan dalam Pilkada, dan hal ini tidak disadari oleh kandidat lainnya. Jaringan di dalam Tim Srikandi dibentuk dari tingkat kabupaten hingga tingkat desa. Hal ini bertujuan agar pada saat Budhi melakukan kampanye di daerah-daerah tertentu, akan memudahkan mobilisasi masa terutama kaum perempuan. Dengan menerapkan jejaring hingga ke level desa, maka Budhi akan lebih mudah memobilisasi massa perempuan saat dirinya melakukan safari politik. la melakukan pendekatan gender untuk mempengaruhi perolehan suaranya.

Sedangkan untuk modal politik, maka Budhi mengandalkan dukungan Partai Demokrat, PPP, serta Partai Golkar. Kegagalannya dalam jalur indepen ditahun 2011, menyadarkan bahwa posisi partai pengusung sangatlah signifikan. Untuk itu, pada Pilkada 2017, Budhi memberikan porsi antar partai pengusung dalam kegiatan kampanye. Dalam pembagiannya, Partai Golkar (Bawono) mendapat porsi untuk 
mengisi jabatan Ketua Tim Kampanye, PPP (Indarto) mendapat porsi untuk mengisi posisi Sekretaris Tim Kampanye, serta Partai Demokrat (Zen Muhammad) mendapat porsi untuk mengisi posisi Bendahara Tim Kampanye. Dengan adanya struktur bersama ini, maka mesin-mesin partai ditingkat bawah akan bisa bekerja untuk melakukan mobilisasi suara dalam Pilkada.

\section{Strategi Politik dalam Bingkai Praktik Sosial}

Dalam sebuah praktik sosial, peran modal, habitus, serta ranah menjadi formula yang harus diperhatikan penggunaannya. Kemenangan Budhi Sarwono sebagai sebuah praktik sosial dilihat dari perumusan strategi politik yang memperhatikan unrus-unsur dalam sebuah praktik sosial. Seorang kandidat harus memutuskan strategi apa yang akan digunakan dengan mempertimbangkan latar belakang modal yang dimiliki, habitus dari masyarakat, serta ranah yang dilalui. Dengan memperhatikan hal-hal tersebut, maka mobilisasi dan kapitalisasi suara saat Pilkada bisa diraih dengan maksimal.

Dalam kategori ranah, pemenang kontestasi politik ditentukan oleh siapa yang mendapat suara paling banyak. Dengan konteks semacam ini, kandidat petahana biasanya akan mendapat keuntungan paling besar karena dirinya bisa memanfaatkan jaringan birokrasi pemerintahan, sekaligus melakukan politik "pork barrel" dengan membuat program-program pemerintah yang sejatinya dipakai untuk meraup suara. Di sini, Budhi jelas bukan petahana, yang memiliki keistimewaan untuk melakukan hal itu. Selain itu, Budhi juga bukan berasal dari kelompok mayoritas. Hal yang berbeda dengan Basuki Tjahaja Purnama (Ahok) yang pernah terpilih menjadi Bupati Belitung Timur, yang secara komposisi warganya juga banyak yang keturunan Tionghoa. Kelompok Tionghoa di Banjarnega tidaklah sebanyak di Belitung Timur.

Mengingat arena yang kurang menguntungkan, maka Budhi harus mencari celah bagaimana strategi politiknya bisa dilangsungkan. Untuk itu, cara yang harus dilakukan adalah dengan mengamati apa habitus masyarakat yang berkembang dalam arena ini. Dalam hal ini, habitus dimanifestasikan dalam bentuk pemikiran atau cara pandang masyarakat terhadap pemerintah daerah Banjarnegara. Citra pemerintah daerah pada saat itu memang tidak cukup positif bagi masyarakat. Hal ini dikarenakan masyarakat merasa pemerintah tidak hadir dalam kehidupan mereka. Hal ini dikonfirmasi oleh PL, salah satu warga yang ditemui peneliti mengakui bahwa, "Ketidakhadiran pemerintah bagi masyarakat dapat dilihat melalui kurangnya perhatian pemerintah terhadap ruas jalan di Banjarnegara yang rusak" (wawancara penulis, 28 Oktober 2019).

Konstruksi cara pandang masyarakat yang melihat jalan yang selalu rusak dan tidak pernah diperbaiki, menjadi celah bagi Budhi untuk dijadikan strategi politiknya. Apalagi dirinya memang seorang kontraktor yang biasa mengerjakan proyek perbaikan jalan. Karena itu, narasi memperbaiki jalan dan infrastruktur kebutuhan lainnya, menjadi 
materi yang sering dipakai berulang-ulang oleh Budhi selama kampanye. Hal ini semua masuk akal karena secara geografis Banjarnegara berada di kawasan dataran tinggi Dieng. Sehingga, rusaknya jalan akan langsung berpengaruh pada kehidupan masyarakat sekitar, karena menjadikan aktifitas sehari-hari berada dalam ancaman bahaya kecelakaan.

Dengan habitus masyarakat yang seperti itu, maka Budhi melanjarkan strategi politiknya dengan memanfaatkan modal yang ia miliki. Modal sosial-budaya yang diperolehnya dari keluarga, khususnya faktor keturunan dari orang tua yang cukup terpandang di Banjarnegara juga ikut menciptakan citra positif. Selain itu, anaknya sendiri yang mengomandai Tim Srikandi, dengan membentuk jejaring-jejaring konstituen dari kalangan perempuan hingga tingkat desa. Sedangkan dari aspek modal politik, Budhi memanfaatkan keberadaan partai politik untuk mendukungnya dalam kontes tersebut. Sebagai contoh, untuk mendapatkan suara dari kalangan santri, Budhi banyak dibantu oleh jejaring politik dari PPP. Hal ini diakui Indarto yang membuka jalur strategi testimonial dari para kyai cukup berpengaruh bagi masyarakat Banjarnegara (wawancara penulis, 21 Oktober 2019).

Selain itu, Budhi juga memoles citranya dengan memaksimalkan media kampanye yang dimilikinya. la mendirikan Budhi Sarwono Center, serta mengelola media sosial (Facebook, Twitter, Website, Instagram) untuk menyasar pemilih muda. Dengan latar belakangnya sebagai pengusaha yang cukup sukses, ia memaksimalkan modal ekonomi yang dimilikinya untuk digunakan dalam pos-pos strategis secara efektif dan efisien. Dengan memanfaatkan ketiga modal tersebut, Budhi bahkan dapat menciptakan modal simbolik untuk dirinya sendiri.

Seluruh kesatuan modal yang dimilikinya, ia gunakan dalam ranah politik. Di mana terjadi pertarungan perebutan kursi tertinggi di Banjarnegara. Sehingga ranah dalam proses ini dimanifestasikan sebagai proses pemilihan pilkada. Seluruh kandidat mengeluarkan senjatanya masing-masing dalam pertarungan tersebut. Kekuatan senjata inilah yang diukur berdasarkan kepemilikan modal. Modal sebagai sebuah pelumas dalam strategi politik tentunya memiliki pengaruh yang cukup signifikan. Nyatanya, tanpa modal yang besar, strategi politik kelas wahid pun hanya akan menjadi strategi belaka tanpa dapat diaplikasikan. Modal yang berada dalam ranah politik diaplikasikan melalui kampanye politik dengan narasi "politik simpatik". Pemilihan tema simpatik dalam strategi politik Budhi Sarwono dilatarbelakangi oleh kepemilikan modalnya, baik modal sosial-budaya, modal politik, maupun modal ekonomi. Budhi melihat potensi yang dimilikinya dari aspek modal untuk diaplikasikan dalam pilkada Banjarnegara pada 2017 silam.

Adanya habitus masyarakat yang sudah cenderung pesimis dengan pemerintahan sebelumnya, menjadikan Budhi untuk menerapkan strategi politik simpatik. Hal ini 
sesuai dengan konsepsi habitus yang merujuk pada sistem disposisi yang berlangsung secara terus menerus yang berfungsi untuk mengatur serta menghasilkan sebuah praktik (Evens, 1999, p. 9). Ini artinya, strategi politik Budhi digunakan untuk menyasar adanya habitus masyarakat berupa disposisi cara pandang masyarakat yang ditinggalkan oleh pemerintahnya.

Hal ini berarti, dalam sebuah praktik sosial, formula yang digunakan harus menggabungkan unsur modal, habitus, serta ranah. Dengan modal maksimal yang dimiliki, maka seseorang dapat mengaplikasikannya pada habitus yang sudah ditentukan pada ranah pertarungan tertentu. Dalam hal ini, Budhi mencoba memanfaatkan modal sosial-budaya, politik, serta ekonominya dalam menarik simpati masyarakat. Budhi mencoba menempatkan masyarakat pada posisi dimana mereka dapat menuntut haknya kepada negara, salah satunya melalui pemerintah daerah. Sehingga masyarakat kemudian merasa dianggap keberadaannya oleh pemerintah. Ini berarti, tema "simpatik" yang diusungnya menjadi tepat sasaran untuk meraih dukungan suara dari masyarakat Banjarnegara.

Strategi politik sebagaimana dijelaskan di atas ekuivalen dengan pernyataan Djarkasi sebagai Kepala Koordinator Lapangan Tim Pemenangan BisSa. Dirinya mengaku bahwa pelaksanaan kampanye dapat berjalan lebih efektif dan efisien karena tim internal sudah mengetahui kelebihan apa saja yang dapat dimanfaatkan pada saat kampanye (wawancara penulis, 21 Oktober 2019). Menurutnya, apabila tim sudah mengetahui kelebihan dan kekurangan pasangan, maka mereka akan lebih bijak dalam memanfaatkan modal yang dimiliki. Sehingga tanpa harus menyerang menggunakan kampanye negatif atau kampanye hitam, tim pemenangan BisSa dapat meraih dukungan masyarakat secara massif. Dengan tema yang dipilih ini, tim juga lebih mudah mengarahkan ke arah mana kampanye akan di bawa. Tema "simpatik" mengarahkan tim untuk mencoba menarik simpati masyarakat melalui penyampaian capaian, janji politik, serta visi misi yang akan dibawa pasangan Budhi-Syamsudin apabila menjabat kelak.

\section{Penutup}

Kesimpulan yang dapat ditarik dari penelitian ini adalah strategi politik akan berjalan efektif jika mempertimbangkan bagaimana komposisi ranah, habitus, dan modal kandidat agar bisa saling terjahit dengan rapi. Kandidat yang bukan petahana, apalagi dari minoritas Tionghoa, harus melihat betul bagaimana irama praktik sosial yang hendak dilakukan. Jika kandidat bisa melakukan sinkronisasi dari logika praktik sosial ini, maka strategi politik akan berjalan secara efektif untuk memobilisasi massa sekaligus suara dalam kompetisi elektoral.

Ada dua relasi yang terbentuk antara strategi politik dengan modal kandidat, yakni relasi searah dan dua arah. Relasi yang bersifat satu arah terjadi pada pemanfaatan 
modal ekonomi dalam strategi politik. Maksudnya, modal ekonomi akan menentukan bagaimana strategi politik yang berlangsung, dan hal ini tidak berlaku sebaliknya bahwa strategi politik bisa meningkatkan modal ekonomi. Sedangkan relasi dua arah terjadi pada pemanfaatan modal sosial-budaya dan modal politik dalam strategi politik. Hal ini dimaksudkan sebagai, modal sosial dan politik, bisa mempengaruhi strategi politik. Sebaliknya juga, strategi politik bisa diarahkan untuk memperkuat modal sosial-budaya dan modal politik. Ini tercermin dari bagaimana Budhi membangun citra politiknya.

Meski demikian, penelitian ini masih memiliki beberapa kekurangan. Celah kekurangan itu diantaranya adalah tidak adanya ruang analisis tentang peran Wakil Bupati Banjarnegara terpilih. Hal ini dikarenakan penulis gagal menemui Wakil Bupati Banjarnegara (baca: Syamsudin) saat penelitian. Selain itu, kelemahan analisis dalam artikel ini juga terjadi karena tiadanya triangulasi dengan kandidat lain yang kalah. Terutama bagaimana kandidat petahana melihat kekalahan dirinya dan kemenangan Budhi-Syamsudin. Meskipun terdapat beberapa kelemahan di atas, sebenarnya ruang itu adalah celah riset lanjutan yang bisa digeluti kembali.

\section{Ucapan Terima Kasih}

Terima kasih kepada Kushandajani dan Fitriyah yang telah memberi beberapa masukan berharga dalam penulisan jurnal ini.

\section{Pendanaan}

Penulis tidak menerima bantuan pembiayaan untuk penelitian, kepenulisan (authorship), dan publikasi dari pihak manapun.

\section{Daftar Pustaka}

Aziz, A. (2017). Rekapitulasi Pilkada Banjarnegara, Pasangan Budi-Syamsuddin Unggul. Retrieved from https://www.merdeka.com/peristiwa/rekapitulasi-pilkadabanjarnegara-pasangan-budi-syamsuddin-unggul.html

Bourdieu, P. (2011). The Forms of Capital (1986). In I. Szeman \& T. Kaposy (Eds.), Cultural theory: An anthology (Vol. 1, pp. 81-93). Singapore: Blackwell.

BPS Kabupaten Banjarnegara. (2018). Penduduk Menurut Jenis Kelamin, Rasio Jenis Kelamin, dan Kecamatan di Kab. Banjarnegara Tahun 2018. Retrieved from https://banjarnegarakab.bps.go.id/statictable/2019/11/25/122/pendudukmenurut-jenis-kelamin-rasio-jenis-kelamin-dan-kecamatan-di-kabbanjarnegara-tahun-2018.html. from Badan Pusat Statistik Kabupaten Banjarnegara 
CNN Indonesia. (2019). Jatuh Bangun Etnis Tionghoa dalam Politik Indonesia. Retrieved from https://www.cnnindonesia.com/nasional/20190205120557-32-366561/ jatuh-bangun-etnis-tionghoa-dalam-politik-indonesia

Creswell, J. W. (2016). Research Design: Pendekatan Metode Kualitatif, Kuantitatif, dan Campuran. Yogyakarta: Pustaka Pelajar.

Evens, T. M. S. (1999). Bourdieu and the Logic of Practice: Is All Giving Indian-Giving or is "Generalized Materialism" Not Enough? For the memory of Louis Dumont. Sociological Theory, 17(1), 3-31.

Fatimah, S. (2018). Kampanye sebagai Komunikasi Politik. Resolusi: Jurnal Sosial Politik, 1(1), 12. doi:10.2489/resolusi.v1i1.154

Hanafi, R. I. (2016). Pemilihan Langsung Kepala Daerah di Indonesia: Beberapa Catatan Kritis untuk Partai Politik. Jurnal Penelitian Politik, 11(2), 16. doi:10.14203/jpp.v11i2.197

Hudayana, B. (2011). Glembuk: Strategi Politik dalam Rekrutmen Elite Penguasa di Desa Pulungansari Yogyakarta. Jurnal Humaniora, 23(1). doi:10.22146/jh.1005

Juliastutik, J. (2010). Perilaku Elit Politik Etnis Tionghoa Pasca Reformasi. Jurnal Humanity, 6(1), 14.

KPU RI. (2017). Pilkada Kabupaten Banjarnegara. Retrieved from https://pilkada2017. kpu.go.id/hasil/t2/jawa_tengah/banjarnegara. Retrieved 02-01, from Komisi Pemilihan Umum Republik Indonesia

Maharddhika. (2016). KPU Targetkan Partisipasi Pemilih 77,5 Persen di Pilkada Serentak 2017. Retrieved from https://rumahpemilu.org/kpu-targetkan-partisipasipemilih-775-persen-di-pilkada-serentak-2017/

Oh, H. (2017). Ambivalensi Kebijakan Pemerintah Orde Baru tentang Golongan Etnis Tionghoa: Suatu Tinjauan Keputusan Presidium Kabinet Nomor 127 Tahun 1966 dan Instruksi Presiden Nomor 14 Tahun 1967. IImu dan Budaya, 40(49).

Paramita, R. P., \& Islahuddin. (2017). Kinerja petahana bukan segalanya. Retrieved from https://lokadata.id/artikel/kinerja-petahana-bukan-segalanya

Ritzer, G. (2012). Teori Sosiologi: Dari Sosiologi Klasik Sampai Perkembangan Terakhir Postmodern. Yogyakarta: Pustaka Pelajar.

Saifuddin, A., Tastrawati, N. K. T., \& Sari, K. (2018). Penerapan Konsep Teori Permainan (Game Theory) dalam Pemilihan Strategi Kampanye Politik: Studi Kasus Strategi Pemenangan Pemilukada DKI Jakarta Tahun 201. E-Jurnal Matematika, 7(2), 7. doi:10.24843/MTK.2018.v07.i02.p200

Schroder, P. (2010). Strategi Politik. Jakarta: Friedrich Noumann Shiftung.

Suhandinata, J. (2009). WNI Keturunan Tionghoa dalam Stabilitas Ekonomi dan Politik Indonesia: PT Gramedia Pustaka Utama. 
Suryadinata, L. (2003). Kebijakan Negara Indonesia terhadap Etnik Tionghoa: Dari Asimilasi ke Multikulturalisme? Antropologi Indonesia, 71, 12. doi:10.7454/ai.v0i71.3464

\section{Daftar Informan:}

Budhi Sarwono, selaku Bupati Banjarnegara terpilih, wawancara 15 Oktober 2019, pukul 08.30 WIB

Djarkasi, selaku Steering Committee Tim Pemenangan BisSa, wawancara 21 Oktober 2019, pukul 09.0 WIB

Indarto, selaku Sekretaris Tim Pemenangan BisSa, wawancara 21 Oktober 2019, pukul 12.15

Endon Priyanto, selaku Mantan Ketua DPC Partai Demokrat Banjarnegara, wawancara 16 Oktober, pukul 09.00 WIB.

PL (nama disamarkan), sebagai tetangga Budhi Sarwono, wawancaran 28 Oktober 2019.

\section{Tentang Penulis}

Krista Yuliani adalah mahasiswa Program Studi S1 Ilmu Pemerintahan, Universitas Diponegoro.

Hendra Try Ardianto adalah dosen Departemen Politik dan Pemerintahan, Universitas Diponegoro. 